\title{
Measurement and Definitions of Obesity In Childhood and Adolescence: A field guide for the uninitiated Helen N Sweeting
}

Address: MRC Social and Public Health Sciences Unit, 4, Lilybank Gardens, Glasgow, G12 8RZ, UK

Email: Helen N Sweeting - helen@sphsu.mrc.ac.uk

Published: 26 October 2007

Nutrition Journal 2007, 6:32 doi:10.1 186/1475-2891-6-32

This article is available from: http://www.nutritionj.com/content/6/I/32

(C) 2007 Sweeting; licensee BioMed Central Ltd.

This is an Open Access article distributed under the terms of the Creative Commons Attribution License (http://creativecommons.org/licenses/by/2.0), which permits unrestricted use, distribution, and reproduction in any medium, provided the original work is properly cited.

\begin{abstract}
This paper aims to guide readers embarking on the complex literature in respect of childhood and adolescent obesity. It opens with a discussion of definitions of 'obesity' based on overall fat levels and the significance of fat distribution. This is followed by simple descriptions of the various techniques used to measure fat, including density-based, scanning, bioelectrical impedance and anthropometric methods. The paper then turns to 'overweight' and the measurement of weight in relation to height, particularly via body mass index (BMI). While it is a relatively simple measure and a valuable tool, BMI has several disadvantages, which are described. These include a lack of consensus on which values should be used to define 'overweight' or 'obese', with the result that the literature contains a confusing multiplicity of child and adolescent obesity rates.
\end{abstract}

\section{Introduction}

At one level, research on child and adolescent obesity rates is easy to understand. Based on recent studies, the BBC News website includes statements such as 'obesity affects $12 \%$ of under-11s' (14 ${ }^{\text {th }}$ December, 2006), and 'Levels of obesity in children aged two to 10 years rose from $9.9 \%$ to $13.4 \%$ between 1995 and 2004, according to the Health Survey for England.' (25th January, 2007). However, for the researcher who wishes to gain a clearer understanding of how obesity is measured, or to delve into these figures in more detail, the literature may prove quite challenging.

One difficulty is that descriptions of the measurement of obesity are littered with acronyms, an understanding of which is often assumed. But for the uninitiated, what do ADP, DXA or BIA stand for? And perhaps even more puzzling, how is it possible to accurately measure levels of fat within a living individual? A second source of puzzlement is apparently conflicting numbers. For example, given that obesity levels are lower in the UK than the US [1], why would one paper report rates for US 12-19 year olds in 1999-2002 of 16\%, but another report rates for English $11-15$ year olds in 2000 of $18 \%[2,3]$ ?

This paper is written by one who was puzzled, and is now less so, to help others embarking upon this literature. It begins with a discussion of the significance of overall fat levels and fat distribution, followed by a description of methods to measure fat. The second half of the paper describes measurements of overweight rather than fat. It focuses particularly on body mass index, since this is by far the most common indicator, exploring how it has been used to define obesity, and how accurately it identifies the fattest children. From this point forwards, terms commonly used in this literature are in bold the first time they appear. 


\section{Obesity, fat levels and fat distribution}

Obesity should be defined as excess body fat or adipose tissue; it is this, not weight which is associated with the comorbid conditions [4]. This being the case, the next question is what level of fat should be defined as 'obese'. Studies of children and adolescents which have examined the relationship between percentage of body fat calculated from skinfold measurements and indicators of biomedical status such as blood pressure and blood lipids, have suggested $30 \%$ fat in females and $20-25 \%$ in males $[5,6]$. There is also evidence of ethnic differences, for example, South Asian people appear to be sensitive to the metabolic consequences of obesity at lower levels than white people [7].

This is further complicated by findings that it is central (also described as intra abdominal - IA, or visceral) fat which is more pathogenic $[4,8]$. Adults with large waist circumferences have excess morbidity, including back pain, diabetes and CVD risk factors [9], and although less clear, there is some evidence of health risks associated with excess abdominal fat in children $[10,11]$. There is also evidence that the excess fat in obese children and adolescents is likely to accumulate in the abdominal regions $[12,13]$.

Overall levels, as well as the distribution of fat, differ according to both sex and ethnicity. The android (male, or 'apple shaped') fat pattern is represented by relatively greater amounts in the upper body, the gynoid (female, or 'pear') pattern by greater amounts in the hip and thigh areas [14]. Female lower body fat is less metabolically active than that in the abdominal region, and is programmed to become mobilized during pregnancy and lactation. In relation to the greater pathogenicity of abdominal fat, it is interesting that mortality rates are higher among females with android fat patterning [8]. Sex differences in fat levels have generally been considered to become manifest during puberty [15]. Thus, in samples followed up through adolescence, levels of fat are higher among females, and of fat-free mass among males [1620]. However, more recent studies of pre-pubertal children, some as young as 3 years old, in the US, UK, Germany, Italy and China, have also found higher percentages of body fat and evidence of the gynoid pattern among females [21-25].

Percentage body fat also appears to be lower in black, perhaps particularly black African children (and adults) compared with Caucasians. In other words, for any given body mass, black African children have higher fat-free and lower fat mass. Levels of abdominal fat also tend to be lower among Black Africans. There is, in addition, some evidence that these differences are more pronounced among females than males $[10,17,21,26]$. In contrast, many Asian races, and possibly also Hispanics and Chinese, carry a higher percentage fat mass than Caucasians $[4,25,26]$.

\section{Methods to measure fat}

Table 1 describes the main techniques which have been adopted to measure fat in human subjects. They are categorized as density-based (hydrodensitometry; air displacement plethysmography), scanning (computerized tomography; magnetic resonance imaging; dual-energy $\mathrm{x}$ ray absorptiometry), bioelectrical impedance and anthropometric (skinfold; waist circumference; waist-hip ratio) methods, according to the general principle on which they are based. More complex and detailed descriptions are available [27-29]. As Table 1 demonstrates, the majority of these methods are complex and limited to research settings.

\section{When fat cannot be measured - weight in relation to height}

In contrast to obesity, which is excess levels of fat, overweight is excess weight in relation to height, and can be easily measured using only a set of scales and a stadiometer. Indeed, it may not even require this; some studies have used self-report weights and heights. However, comparisons with measured values show that although correlations are high, weight tends to be under-reported, particularly among females and the overweight, while height may be over-reported. There is a lack of consensus on the impact that this has on measures of weight in relation to height, some authors suggesting that self-report values are adequate [30], others advocating caution [31,32].

\section{Measures of weight in relation to height}

Although body weight, particularly at very high levels, tends to be associated with adiposity, weight alone is an insufficient measure of obesity, because it is correlated with height [33]. A number of measures of weight in relation to height have been devised. The simplest is weight for height. In 1977 a World Health Organization (WHO) bulletin noted that in undernourished populations, $80 \%$ median weight for height (which corresponds to approximately -2.0 standard deviations) was suitable for classifying malnourished children. Following this principle, it was suggested that $120 \%$ (or +2.0 standard deviations) could be used in populations where over-nutrition was a problem [34]. Although adopted in some recent studies $[35,36]$, such measures tend not to be used currently. Body Mass Index (BMI), defined as weight $(\mathrm{kg}) /$ height squared $\left(\mathrm{m}^{2}\right)$ is the most frequently used measure of weight in relation to height, but there are others. These include Rohrer's Ponderal Index (termed either Rohrer's Index - RI, or the Ponderal Index - PI), defined as weight/height ${ }^{3}$. This has been compared with BMI in 
Table I: Methods to measure fat

\begin{tabular}{|c|c|c|c|c|c|c|}
\hline & General principle & Method & Acronym & Methodology & $\begin{array}{l}\text { Method-specific } \\
\text { principle }\end{array}$ & $\begin{array}{l}\text { Further } \\
\text { comments }\end{array}$ \\
\hline \multirow[t]{2}{*}{$\begin{array}{l}\text { Density-based } \\
\text { methods }\end{array}$} & $\begin{array}{l}\text { If the density (weight } \\
\text { per unit volume) of a } \\
\text { human body is known, } \\
\text { then the relative } \\
\text { proportions of fat and } \\
\text { fat-free mass can be } \\
\text { estimated using an } \\
\text { equation such as those } \\
\text { of Siri [72] or Lohman } \\
\text { [73]. While mass can } \\
\text { be easily determined by } \\
\text { weighing, volume } \\
\text { measurements are } \\
\text { more difficult [74]. }\end{array}$ & $\begin{array}{l}\text { Hydrodensitometry } \\
\text { (underwater weighing) }\end{array}$ & UWW & $\begin{array}{l}\text { Weighs the subject } \\
\text { while submerged in a } \\
\text { large tank (having } \\
\text { exhaled maximally) } \\
\text { and also outside the } \\
\text { tank [29]. }\end{array}$ & $\begin{array}{l}\text { Based on Archimedes' } \\
\text { principle (buoyancy law) } \\
\text { that if the density of an } \\
\text { object exceeds that of } \\
\text { water, it will sink. Given } \\
\text { two people of equivalent } \\
\text { weight outside the tank, } \\
\text { the one with more fat, } \\
\text { which is less dense than } \\
\text { water, will weight less in } \\
\text { water than the one with } \\
\text { more fat-free tissue } \\
\text { (such as bone and } \\
\text { muscle) which is more } \\
\text { dense than water [75]. } \\
\text { (In fact, it is unnecessary } \\
\text { to actually weight the } \\
\text { subject underwater, } \\
\text { since their volume can } \\
\text { also be assessed via the } \\
\text { amount of water } \\
\text { displaced when they are } \\
\text { submerged.) }\end{array}$ & $\begin{array}{l}\text { Often described as 'the } \\
\text { gold standard', but time- } \\
\text { consuming and requires } \\
\text { the subject to submerge } \\
\text { themselves, so } \\
\text { particularly unsuitable } \\
\text { for certain populations, } \\
\text { such as children, and } \\
\text { limited to research } \\
\text { settings [76]. }\end{array}$ \\
\hline & & $\begin{array}{l}\text { Air Displacement } \\
\text { Plethysmography }\end{array}$ & ADP & $\begin{array}{l}\text { Measures the volume } \\
\text { of air the subject } \\
\text { displaces inside an } \\
\text { enclosed chamber. }\end{array}$ & $\begin{array}{l}\text { Given the subject's } \\
\text { volume and weight, their } \\
\text { density can be } \\
\text { calculated. }\end{array}$ & $\begin{array}{l}\text { Early plethysmographs } \\
\text { were complex, } \\
\text { inconvenient and } \\
\text { required temperature- } \\
\text { controlled surroundings. } \\
\text { A simple, quick } \\
\text { automated } \\
\text { plethysmograph [77] has } \\
\text { been available since mid } \\
\text { 1990s, but is still limited } \\
\text { to research settings } \\
\text { [74]. }\end{array}$ \\
\hline \multirow[t]{2}{*}{ Scanning methods } & $\begin{array}{l}\text { Can assess not just } \\
\text { overall fat mass, but } \\
\text { also its regional } \\
\text { distribution. }\end{array}$ & $\begin{array}{l}\text { Computerised } \\
\text { Tomography; Magnetic } \\
\text { Resonance Imaging }\end{array}$ & CT; MRI & $\begin{array}{l}\mathrm{CT} \text { - a series of } x \text {-rays } \\
\text { pass through the body } \\
\text { at different angles. } \\
\mathrm{MRI} \text { - uses a strong } \\
\text { magnetic field and a } \\
\text { radio wave antenna } \\
\text { which sends signals to } \\
\text { the body and then } \\
\text { receives them back. } \\
\text { These are used to } \\
\text { produce internal } \\
\text { images. }\end{array}$ & $\begin{array}{l}\text { Both allow for the } \\
\text { creation of cross- } \\
\text { sectional high-resolution } \\
\text { internal images. }\end{array}$ & $\begin{array}{l}\text { Expensive, involve } \\
\text { radiation exposure (CT) } \\
\text { and limited to research } \\
\text { settings [27-29]. }\end{array}$ \\
\hline & & $\begin{array}{l}\text { Dual-Energy X-ray } \\
\text { Absorptiometry }\end{array}$ & $\begin{array}{l}\text { DEXA or } \\
\text { DXA }\end{array}$ & $\begin{array}{l}\text { A series of transverse } \\
\text { scans, via low energy } \\
\text { x-ray beams, progress } \\
\text { inch-by-inch across } \\
\text { the body and are } \\
\text { collected by an } \\
\text { external detector. }\end{array}$ & $\begin{array}{l}\text { The beams are } \\
\text { differentially absorbed } \\
\text { by the various different } \\
\text { tissues (fat, bone, etc) in } \\
\text { the body. }\end{array}$ & $\begin{array}{l}\text { Can be used to calculate } \\
\text { fat and fat-free mass, and } \\
\text { both total and regional } \\
\text { body composition in } \\
\text { subjects over a wide } \\
\text { range of ages and body } \\
\text { sizes. Relatively low } \\
\text { radiation dose. Validated } \\
\text { against UWW and } \\
\text { comparison with animal } \\
\text { carcasses in the } \\
\text { pediatric weight range. } \\
\text { Use limited to research } \\
\text { settings }[27,28,46,78, \\
79] \text {. }\end{array}$ \\
\hline $\begin{array}{l}\text { Bioelectrical } \\
\text { impedance methods }\end{array}$ & $\begin{array}{l}\text { Electric currents pass } \\
\text { more easily through } \\
\text { body fluids in muscle } \\
\text { and blood, but } \\
\text { encounter resistance } \\
\text { ('biolectical } \\
\text { impedance') when they } \\
\text { pass thorugh fat, since } \\
\text { it contains little water. }\end{array}$ & $\begin{array}{l}\text { Bioelectrical Impedance } \\
\text { Analysis }\end{array}$ & $\mathrm{BIA}$ & $\begin{array}{l}\text { Conductors are } \\
\text { attached to the } \\
\text { subject's body, and a } \\
\text { low, safe, current is } \\
\text { sent through. } \\
\text { Electrodes are } \\
\text { generally placed at } \\
\text { wrist and ankle; an } \\
\text { increasingly commonly } \\
\text { used analyser requires } \\
\text { subjects to stand on it } \\
\text { in bare feet and hold a } \\
\text { handgrip in each hand. } \\
\text { Foot-to-foot BIA } \\
\text { measures the } \\
\text { impedance of the } \\
\text { lower body and only } \\
\text { requires the subject to } \\
\text { stand on pad } \\
\text { electrodes. }\end{array}$ & $\begin{array}{l}\text { The resistance between } \\
\text { the conductors provides } \\
\text { a measure of body fat. }\end{array}$ & $\begin{array}{l}\text { Although less accurate } \\
\text { than more sophisticated } \\
\text { measurements, some } \\
\text { current analysers are } \\
\text { relatively inexpensive, } \\
\text { portable, simple and } \\
\text { quick, meaning BIA can } \\
\text { now be used in the field } \\
\text { and with large samples } \\
{[20,80] \text {. }}\end{array}$ \\
\hline
\end{tabular}


Table I: Methods to measure fat (Continued)

\begin{tabular}{|c|c|c|c|c|c|c|}
\hline \multirow[t]{3}{*}{$\begin{array}{l}\text { Anthropometric } \\
\text { methods }\end{array}$} & \multirow[t]{3}{*}{$\begin{array}{l}\text { Direct measurements } \\
\text { of various body } \\
\text { parameters. }\end{array}$} & Skinfold measurements & SF & $\begin{array}{l}\text { Subcutaneous (but not } \\
\text { internal) fat is } \\
\text { measured by firmly } \\
\text { grasping a fold of skin } \\
\text { with callipers and } \\
\text { raising it, with no } \\
\text { muscle included. } \\
\text { Single site } \\
\text { measurements, e.g. } \\
\text { triceps skinfolds [16] } \\
\text { are simplest. An } \\
\text { alternative is to add } \\
\text { skinfolds from a } \\
\text { variety of sites, } \\
\text { generally representing } \\
\text { both peripheral and } \\
\text { trunk areas [I7]. }\end{array}$ & $\begin{array}{l}\text { Subcutaneous fat may be } \\
\text { taken as an indicator of } \\
\text { total fat. Fat distribution } \\
\text { can also be determined } \\
\text { via the ratio of trunk to } \\
\text { peripheral skinfolds [8I]. } \\
\text { It is also possible to } \\
\text { calculate total body fat } \\
\text { via equations: Slaughter's } \\
\text { equations predict } \\
\text { percent body fat from } \\
\text { the sum of triceps plus } \\
\text { subscapular, or triceps } \\
\text { plus calf in children and } \\
\text { young people [82]; more } \\
\text { recent equations by } \\
\text { Dezenberg use triceps } \\
\text { skinfolds plus body } \\
\text { weight, sex and ethnicity } \\
\text { [83]. }\end{array}$ & $\begin{array}{l}\text { Cheap and fairly simple, } \\
\text { but the need to partially } \\
\text { undress may put some } \\
\text { subjects off, leading to } \\
\text { bias. Also difficult to } \\
\text { measure reproducibly, } \\
\text { particularly if the subject } \\
\text { is fat [84]. }\end{array}$ \\
\hline & & Waist circumference & WC & $\begin{array}{l}\text { Ideally measured using } \\
\text { a flexible plastic tape } \\
\text { with a sprung handle } \\
\text { to ensure } \\
\text { reproducible levels of } \\
\text { tension [29]. Since a } \\
\text { potential source of } \\
\text { error is incorrectly } \\
\text { positioning the tape, } \\
\text { the measurement site } \\
\text { is generally specified } \\
\text { by reference to } \\
\text { specific anatomic } \\
\text { landmarks [85]. }\end{array}$ & $\begin{array}{l}\text { WC reflects total and } \\
\text { abdominal fat levels, and } \\
\text { as an indicator of } \\
\text { adiposity is not greatly } \\
\text { influenced by height } \\
\text { [86]. }\end{array}$ & $\begin{array}{l}\text { WC centiles for children } \\
\text { have been developed in } \\
\text { a number of countries } \\
\text { [86-89]. It has also } \\
\text { recently been suggested } \\
\text { that the ratio of waist to } \\
\text { height could be used as a } \\
\text { rapid screening tool } \\
\text { [90]. }\end{array}$ \\
\hline & & Waist-hip ratio & WHR & & $\begin{array}{l}\text { A larger WHR in adults } \\
\text { indicates relatively larger } \\
\text { amounts of abdominal } \\
\text { fat and has been used to } \\
\text { describe body fat } \\
\text { distribution. However it } \\
\text { is influenced by several } \\
\text { other bodily factors and } \\
\text { there is some evidence } \\
\text { that it is a poorer } \\
\text { measure of body fat } \\
\text { distribution in children } \\
\text { [9/]. }\end{array}$ & $\begin{array}{l}\text { Infrequently used in } \\
\text { studies of children and } \\
\text { adolescents. }\end{array}$ \\
\hline
\end{tabular}

respect of its ability to predict percentage body fat in children and adolescents, and its long-term associations with adult obesity $[37,38]$. Although it may perform as well or better in some respects than BMI, it is much less used with children and adolescents, although it remains popular with neonatologists [39]. Finally, there is Benn's Index, defined as weight/height ${ }^{\mathrm{p}}$ where the power $\mathrm{p}$ is chosen so the index is independent of height. While this may be 'the ideal index' ([39], p.289), the fact that p is neither constant, nor necessarily a whole number, means the calculations are very complicated, and such indices are rarely used $[40,41]$.

\section{Body Mass Index}

As noted above, BMI is the most frequently used measure of weight in relation to height. It has been described as 'the backbone of the obesity classification system and surveillance statistics ... an immensely valuable tool' ([4], p.141). However, a number of authors have detailed its disadvantages [42-45].

The first of these is that BMI varies between males and females and according to age and level of maturity. Thus, while male and female BMIs tend to be similar in child- hood, they are higher among females in adolescence. In respect of age, BMI increases from birth to around one year, then declines to around age six, then increases through the remainder of childhood and adolescence. The point at which BMI reaches its lowest level and begins to increase is termed 'adiposity rebound', with earlier adiposity rebound being associated with increased risk of subsequent overweight [46]. Such variations mean that among children and adolescents the significance of any particular BMI is more difficult to determine than within adult populations.

A second, and related limitation of BMI, is that it reflects both fat and fat-free components of body weight. However, as described earlier, populations differ in respect of both percentage fat mass and fat distribution, and in the relation between body composition and morbidity. This means, again, that the significance of any particular BMI will vary. Thus, among children with the same BMI, fat measurements are higher for whites than for blacks [47]. Further, recent studies have suggested that increases in overall BMIs have been accompanied by larger increases in the percentage as fat mass and concomitant decreases in fat free mass (attributed to reduced activity levels). 
Importantly, this suggests that recent increases in adiposity are even greater than those suggested by increases in BMI $[13,23,48]$.

A third disadvantage of BMI is that since one of its components is height, the index also varies according to height, and this association in turn varies according to sex and age. Its relationship to height means that BMI is also affected by relative leg length.

A further disadvantage is that since BMI does not measure fat directly, there is no consensus about which cut-off to use in order to define obesity in children and adolescents. Among adults, a WHO Expert Committee on Physical Status agreed, in 1993, to classify BMIs as follows: 25-29.9 as 'overweight' (or 'pre-obese'); 30-34.9 as 'obese class I'; 35-39.9 as 'obese class II'; and over 40 as 'obese class III'. This classification was based on the risk of comorbidities, rising across the four categories from 'increased', to 'moderate', 'severe' and 'very severe' $[49,50]$. Unfortunately, much less is known about levels of risk associated with specific BMI levels in children and adolescents. This means that statistical approaches have often been used. These involve working out the distribution for a particular population and rather arbitrarily choosing particular values - often the $85^{\text {th }}$ or $95^{\text {th }}$ centiles, which distinguish those with the highest BMIs from the rest of the population [33]. Since the distribution of BMI varies according to sex, age and ethnicity, sex- and age- (and, sometimes, in the US, race-) specific centile curves are calculated.

\section{BMI and overweight/obesity - where to draw the line?}

Clearly, if the aim is to track levels of obesity over time, or to compare populations, the BMI centile values defining obesity must be fixed. The question is not only which centile they should be fixed at, but also which population (and so which point in time) should be used as the basis for the calculations?

Within the US, reference growth charts based on nationally representative surveys (the National Health Examination Surveys - NHES, later called the National Health and Nutrition Examination Surveys - NHANES) have been produced since 1977 [51], and in 1991, race-specific and population-based BMI centiles, covering ages 6-74 were generated. These are often described as the MDD definitions, based on the initial letters of the authors' surnames [52]. An expert committee recommended their use for children and adolescents, with the 95 $5^{\text {th }} \mathrm{BMI}$ centile for age and sex (or BMI $30 \mathrm{~kg} / \mathrm{m}^{2}$ ) as cut-offs for 'overweight', and the $85^{\text {th }}$ centile as 'at risk of overweight' for screening purposes. The fact that the committee decided not to use the term 'obese' (which they associated with excess fat rather than weight) [53] has lead to some confusion [33]. The most recent US charts were produced by the Centers for Disease Control in 2000 (hence termed 'CDC 2000'). The inclusion of more recent data would have shifted the weight and BMI curves upwards, resulting in a high proportion of fatter children being characterized as 'normal'. In order to avoid this, data obtained since 1988 from those aged over 6 years were excluded [54]. These charts also tend to be used within Canada and Australia.

Within the UK, charts ('UK90') have been produced, based on data from several surveys, conducted 1978-90 and including around 30,000 subjects. Although the authors suggested the $98^{\text {th }}$ centile, which at age 20 is 29.0 $\mathrm{kg} / \mathrm{m}^{2}$ (thus close to the adult definition of $30 \mathrm{~kg} / \mathrm{m}^{2}$ ) as 'a reasonable definition of child obesity' ([55], p.28), the $95^{\text {th }}$ centile is more commonly adopted for epidemiological purposes. Similar BMI-for-age sex-specific reference charts have been developed in several other European countries including France, Germany and Denmark [5658].

Against this background, the International Obesity Task Force (IOTF), a global network of expertise, concluded that the definition of obesity in children and adolescents should be consistent with that for adults, and that, ideally, it should be based on a reference representative of the world's population [59]. Subsequently, data from 6 countries, collected 1963-93, was pooled, and in 2000, centile curves were published that pass through the points of 25 $\mathrm{kg} / \mathrm{m}^{2}$ and $30 \mathrm{~kg} / \mathrm{m}^{2}$ (reflecting WHO recommended definitions of adult overweight and obese) at age 18 [60]. In fact, the available reference data do not adequately represent the world's population. Further, as noted earlier, ethnic differences in body composition and the percentage of body fat associated with adverse health consequences mean that a single international definition of obesity may not be appropriate [44]. However, it has been suggested that despite these limitations, prevalence studies should present results based on the IOTF cut-offs as well as national definitions, since this would allow for comparison across populations [61].

The confusing multiplicity of child and adolescent obesity rates seen in the literature results from the use of different definitions; a number of studies have demonstrated this by applying several definitions to the same population. For example, one US study found rates of $13 \%, 11 \%$ and $8 \%$ when applying the MDD 'overweight', CDC 2000 'overweight' and IOTF 'obesity' criteria to (1998-1994) data in respect of 6-8 year old males [62]. Similarly, a UK study of 4-11 year olds (1994 data) found male and female obesity rates of $1.7 \%$ and $2.6 \%$ when applying the IOTF definition, but of $2.5 \%$ and $2.2 \%$ when applying the UK90 definition. Thus, while the IOTF definition suggested higher rates among females, the reverse was suggested by the UK90 definition [63]. 
Crucially, given that BMI measures excess weight rather than fat, studies have also examined the accuracy with which it identifies the fattest children and adolescents. This translates into its sensitivity (how good it is at identifying the truly obese) and specificity (how good it is at identifying the non-obese). Ideally, this requires a definition of 'true' obesity, however, as described earlier, this is lacking. Studies have therefore adopted a variety of methods. These include correlating BMI with percentage body fat (measured in various ways); comparing BMI-defined obesity (various different cutoffs) with obesity defined in terms of percentage body fat (also various different cutoffs, generally around $30 \%$ for females and $20-25 \%$ for males - see earlier and [5,6]); comparing BMI-defined obesity with percent body fat levels deemed 'high' (typically $85^{\text {th }}$ or $95^{\text {th }}$ percentile); and finally, comparing cardiovascular risk factors among those defined via BMI as obese and non-obese [64-67]. The consensus from such studies is that BMI is a reasonable measure of adiposity, although the relationship differs not only according to age, sex and ethnicity, but also degree of fatness, being better at high levels. This means that it is of more use in epidemiological studies, but is relatively poor at predicting fat mass in any individual child. Further, current BMI cutoffs have relatively high specificity, but lower sensitivity. This means that non-obese children are unlikely to be wrongly labeled, however obese children may be missed (for example, see [22,68-70]).

\section{Conclusion}

Increasing rates - regardless of definition - have highlighted the importance of the measurement of child and adolescent obesity on a population level. However 'obesity' is a slippery concept. Even the WHO definitions of 'overweight' and 'obesity' adopted for use with adults are based on BMI levels associated with raised risks of comorbidities. However, $25 \mathrm{~kg} / \mathrm{m}^{2}$ and $30 \mathrm{~kg} / \mathrm{m}^{2}$ are also easily remembered, neat and tidy numbers. Other definitions would have been possible. In fact, lower cut-offs have subsequently been suggested for Asians, given their tendency to both carry a higher percentage fat and be more sensitive to its metabolic consequences [71].

Decisions in respect of children are even more complex. As with adults, the relationships between BMI and levels of fat, and between levels of fat and associated morbidities, differ between ethnic groups. In addition, BMI levels, and their relationship with levels of fat vary according to sex, age and maturity. This has resulted in attempts to define obesity on the basis of percentage body fat, waist circumference and, most frequently, BMI, which reflects weight in relation to height. The consequence of this is that different studies may define obesity in different ways. None could be said to be 'correct' [62]. It has been argued that efforts to assess body fat and develop population standards against which individuals can be compared should be increased [4]. However, even this would require decisions as to cutoffs.

The literature in this area can be confusing. While that seems unlikely to change in the near future, this guide may increase the understanding of those embarking upon it.

\section{Acknowledgements}

The author would like to thank Professors Sally Macintyre and Patrick West and Dr. Seeromanie Harding for comments on an earlier draft. The author is funded by the UK Medical Research Council. This paper was funded in part by the European Men's Health Development Foundation.

\section{References}

I. Association for the Study of Obesity (ASO): Obesity: the scale of the problem - fact sheet. [http://www.aso.org.uk].

2. Baskin ML, Ard J, Franklin F, Allison DB: National prevalence of obesity: Prevalence of obesity in the United States. Obesity Reviews 2005, 6(I):5-7.

3. Information Centre for Health and Social Care: Health Survey for England 2004. Updating of trend tables to include childhood obesity data. [http://www.ic.nhs.uk].

4. Prentice A, Jebb SA: Beyond body mass index. Obesity Reviews 200I, 2: $|4|-\mid 47$

5. Williams DP, Going SB, Lohman T, Harsha DW, Srinivasan S, Webber LS, Berenson G: Body fatness and risk for elevated blood pressure, total cholesterol, and serum lipoprotein ratios in children and adolescents. American Journal of Public Health 1992, 82:358-363.

6. Dwyer T, Blizzard CL: Defining obesity in children by biological endpoint rather than population distribution. International Journal of Obesity 1996, 20(5):472-480.

7. Whincup P, Gilg J, Papacosta O, Seymour C, Miller G, Alberti K, Cook $D$ : Early evidence of ethnic differences in cardiovascular risk: cross sectional comparison of British South Asian and white children. British Medical Journal 2002, 324: I-6.

8. Lev-Ran A: Human obesity: an evolutionary approach to understanding our bulging waistline. Diabetes/Metabolism Research Reviews 2001, I 7(5):347-362.

9. Lean MEJ, Han TS, Seidell J: Impairment of health and quality of life in people with large waist circumference. Lancet 1998, 35 I:853-856.

10. Goran MI, Gower B: Relation between visceral fat and disease risk in children and adolescents. American Journal of Clinical Nutrition 1999, 70 (suppl): |49S- I56S.

II. Maffeis C, Pietrobelli A, Grezzani A, Provera S, Tato L: Waist circumference and cardiovascular risk factors in prepubertal children. Obesity Research 200I, 9(3): 179-187.

12. Moreno LA, Fleta J, Mur L, Sarria A, Bueno M: Fat distribution in obese and nonobese children and adolescents. Journal of Pediatric Gastroenterology \& Nutrition 1998, 27(2): | 76-I80.

13. McCarthy HD, Ellis SM, Cole TJ: Central overweight and obesity in British youth aged I I- I 6 years: cross sectional surveys of waist circumference. BMJ 2003, 326(7390):624.

14. Legato MJ: Gender-specific aspects of obesity. International Journal of Fertility \& Women's Medicine 1997, 42(3): I84- 197.

15. Lobstein T, Baur LA, Uauy R: Obesity in children and young people: a crisis in public health. Obesity Reviews 2004, 5 (Suppl. I):4-85.

16. Bray GA, DeLany JP, Harsha DW, Volaufova J, Champagne CM: Body composition of African American and white children: A 2year follow-up of the BAROC study. Obesity Research 2001, 9(1 0):605-621.

17. Dai SF, Labarthe DR, Grunbaum JA, Harrist RB, Mueller WH: Longitudinal analysis of changes in indices of obesity from age 8 years to age 18 years. American Journal of Epidemiology 2002, I 56(8):720-729.

18. Guo SS, Chumlea WC, Roche AF, Siervogel RM: Age- and maturity-related changes in body composition during adolescence 
into adulthood: The Fels Longitudinal Study. International Journal of Obesity 1997, 2 I(12): I I67-I I75.

19. Demerath EW, Schubert CM, Maynard LM, Sun SS, Chumlea WC, Pickoff $A$, Czerwinski SA, Towne B, Siervogel RM: Do changes in body mass index percentile reflect changes in body composition in children? Data from the Fels Longitudinal Study. Pediatrics 2006, II 7(3): e487-95.

20. McCarthy HD, Cole TJ, Fry T, Jebb SA, Prentice AM: Body fat reference curves for children. International Journal of Obesity 2006, 30(4):598-602.

21. Goran MI, Hunter G, Nagy TR, Johnson R: Physical activity related energy expenditure and fat mass in young children. International Journal of Obesity 1997, 2 I(3): I7I-I78.

22. Bedogni G, lughetti L, Ferrari M, Malavolti M, Poli M, Bernasconi S, Battistini N: Sensitivity and specificity of body mass index and skinfold thicknesses in detecting excess adiposity in children aged 8- 12 years. Annals of Human Biology 2003, 30(2): $132-139$.

23. Ruxton $\mathrm{CH}$, Reilly JJ, Kirk TR: Body composition of healthy 7and 8-year-old children and a comparison with the 'reference child'. International Journal of Obesity 1999, 23:|276-128|.

24. Mast M, Kortzinger I, Konig E, Muller MJ: Gender differences in fat mass of 5-7-year old children. International Journal of Obesity 1998, 22(9):878-884.

25. Li S, Zhang M, Yang S, Okada T, Iwata F, Harada K: Age- and sexspecific body composition of Chinese children. Acta Paediatrica 2005, 94(8): I | 39-| | |42.

26. Freedman DS, Wang J, Maynard LM, Thornton JC, Mei Z, Pierson Jr RN, Dietz WH, Horlick M: Relation of BMI to fat and fat-free mass among children and adolescents. International Journal of Obesity 2005, 29(I): I-8.

27. Ellis KJ: Selected body composition methods can be used in field studies. Journal of Nutrition 200 I, I 3 I:1589s-1595s.

28. Pietrobelli A, Peroni DG, Faith MS: Pediatric body composition in clinical studies: which methods in which situations? Acta Diabetologica 2003, 40 Suppl I:S270-3.

29. Pietrobelli A, Tato L: Body composition measurements: From the past to the future. Acta Paediatrica, International Journal of Paediatrics, Supplement 2005, 94(448):8-13.

30. Goodman E, Hinden BR, Khandelwal S: Accuracy of teen and parental reports of obesity and body mass index. Pediatrics 2000, I06(I Pt I):52-58.

31. Brener ND, McManus T, Galuska DA, Lowry R, Wechsler H: Reliability and validity of self-reported height and weight among high school students. Journal of Adolescent Health 2003, 32(4):28I-287.

32. Himes JH, Hannan P, Wall M, Neumark-Sztainer D: Factors associated with errors in self-reports of stature, weight and body mass index in Minnesota adolescents. Annals of Epidemiology 2004, 15:272-278.

33. Troiano RP, Flegal KM: Overweight prevalence among youth in the United States: Why so many different numbers? International Journal of Obesity 1999, 23, Suppl 2:S22-S27.

34. Waterlow JC, Buzina R, Keller W, lane JM, Nichman MZ, Tanner JM: The presentation and use of height and weight data for comparing the nutritional status of groups of children under the age of 10 years. Bulletin of the World Health Organization 1977, 55(4):489-498.

35. Al-Isa AN, Moussa MAA: Nutritional status of Kuwaiti elementary school children aged 6-10 years: comparison with the NCHS/CDC reference population. International Journal of Food Sciences and Nutrition 2000, 5 I (4):22I-228.

36. Chu NF: Prevalence and trends of obesity among school children in Taiwan - The Taipei Children Heart Study. International Journal of Obesity 200I, 25(2): 170-I76.

37. Mei ZG, Grummer-Strawn LM, Pietrobelli A, Goulding A, Goran MI, Dietz WH: Validity of body mass index compared with other body-composition screening indexes for the assessment of body fatness in children and adolescents. American Journal of Clinical Nutrition 2002, 75(6):978-985.

38. Valdez R, Greenlund KJ, Wattigney WA, Bao W, Berenson GS: Use of weight-for-height indices in children to predict adult overweight: the Bogalusa Heart Study. International Journal of Obesity \& Related Metabolic Disorders: Journal of the International Association for the Study of Obesity 1996, 20(8):715-72I.
39. Cole TJ, Henson GL, Tremble JM, Colley NV: Birthweight for length: ponderal index, body mass index or Benn index? Annals of Human Biology 1997, 24(4):289-298.

40. Chinn S, Rona R, Gulliford MC, Hammond J: Weight-for-height in children aged 4-12 years. A new index compared to the normalised body mass index. European Journal of Clinical Nutrition 1992, 46:489-500.

41. Poskitt EM: Defining childhood obesity: the relative body mass index (BMI). Acta Paediatrica 1995, 84:961-963.

42. Garn SM, Leonard WR, Hawthorne VM: Three limitations of the body mass index. American Journal of Clinical Nutrition 1986, 44:996-997.

43. Livingstone MB: Childhood obesity in Europe: a growing concern. Public Health Nutrition 200I, 4(IA): 109-1 I6.

44. Wang Y: Epidemiology of childhood obesity - Methodological aspects and guidelines: What is new? International Journal of Obesity 2004, 28(SUPPL. 3):S2I-S28.

45. McCarthy HD, Jarrett KV, Emmett PM, Rogers I: Trends in waist circumferences in young British children: a comparative study. International Journal of Obesity 2005, 29(2): I57-162.

46. Eisenmann JC, Heelan KA, Welk GJ: Assessing body composition among 3- to 8-year old children: anthropometry, BIA and BXA. Obesity Research 2004, I 2(1 0): 1633-1640.

47. Daniels SR, Khoury PR, Morrison JA: The utility of body mass index as a measure of body fatness in children and adolescents: differences by race and gender. Pediatrics 1997, 99(6):804-807.

48. Wells J, Coward WA, Cole TJ, Davies P: The contribution of fat and fat-free tissue to body mass index in contemporary children and the reference child. International Journal of Obesity 2002, 26:1323-1328.

49. WHO: Physical status: the use and interpretation of anthropometry. Geneva, World Health Organisation, Technical Report Series, 854; 1995.

50. WHO: Obesity: preventing and managing the global epidemic. Report of a WHO consultation on obesity. Geneva, World Health Organisation; 1998.

5I. Hamill PV, Drizd TA, Johnson CL, Reed RB, Roche AF, Moore WM: Physical growth: National Center for Health Statistics percentiles. American Journal of Clinical Nutrition 1979, 32:607-629.

52. Must A, Dallal GE, Dietz WH: Reference data for obesity: 85th and 95th percentiles of body mass index $\left(w t / h t^{2}\right)$ and triceps skinfold thickness. American Journal of Clinical Nutrition 1991, 53:839-846.

53. Himes JH, Dietz WH: Guidelines for overweight in adolescent preventive services: recommendations from an expert committee. American Journal of Clinical Nutrition 1994, 59:307-316.

54. Kuczmarski RJ, Ogden CL, Grummer-Strawn LM, Flegal KM, Guo SS Wei R, Mei Z, Curtin LR, Roche AF, Johnson CL: CDC Growth Charts: United States. In Advance data from vital and health statistics Volume 3/4. Hyattsville, Maryland, National Center for Health Statistics; 2000.

55. Cole TJ, Freeman JV, Preece MA: Body mass index reference curves for the UK, 1990. Archives of Disease in Childhood 1995, 73(I):25-29.

56. Rolland-Cachera MF, Cole T], Sempe M, Tichet J, Rossignol C, Charraud $A$ : Body mass index variations: centiles from birth to 87 years. European Journal of Clinical Nutrition I99|, 45: I3-2I.

57. Kromeyer-Hauschild K, Wabitsch T, Geller F, Ziegler PJ, Geiss LS, Hesse V, Hippel A, Jaeger U, Johnsen D, Keiss W, Korte W, Kunze D, Menner K, Muller M, Niemann-Pilatus A, Remer T, Schaefer F, Wittchen HU, Zabransky S, Zellner K, Hedebrand J: Perzentile fur den Body Mass Index fur das Kindesund Jugendalter unter Heranziehung verschiedener deutscher Stichproben. Monatszeitschrift Kinderheilkunde 200I, I49:807-8I8.

58. Nysom K, Molgaard C, Hutchings B, Michaelsen KF: Body mass index of 0 to 45-y-old Danes: reference values and comparison with published European reference values. International Journal of Obesity 200I, 25(2): $177-184$.

59. Bellizzi MC, Dietz WH: Workshop on childhood obesity: summary of the discussion. American Journal of Clinical Nutrition 1999, 70: 173S-175S.

60. Cole TJ, Bellizzi MC, Flegal KM, Dietz WH: Establishing a standard definition for child overweight and obesity worldwide: international survey. British Medical Journal 2000, 320(7244): 1240-1243. 
61. Chinn S: Definitions of childhood obesity: current practice. European Journal of Clinical Nutrition 2006, I 0: I I89-I I 94.

62. Flegal KM, Ogden CL, Wei R, Kuczmarski RL, Johnson CL: Prevalence of overweight in US children: comparison of US growth charts from the Centers for Disease Control and Prevention with other reference values for body mass index. American Journal of Clinical Nutrition 200I, 73(6): 1086-1093.

63. Chinn S, Rona RJ: International definitions of overweight and obesity for children: a lasting solution? Annals of Human Biology 2002, 29(3):306-3।3.

64. Rodriguez G, Moreno LA, Blay MG, Blay VA, Garagorri JM, Sarria A, Bueno $M$ : Body composition in adolescents: measurements and metabolic aspects. International Journal of Obesity \& Related Metabolic Disorders: Journal of the International Association for the Study of Obesity 2004, 28 Suppl 3:S54-8.

65. Wickramasinghe VP, Cleghorn GJ, Edmiston KA, Murphy AJ, Abbott RA, Davies PS: Validity of BMI as a measure of obesity in Australian white Caucasian and Australian Sri Lankan children. Annals of Human Biology 2005, 32(1):60-7I.

66. Zimmermann MB, Gubeli C, Puntener C, Molinari L: Detection of overweight and obesity in a national sample of 6-12-y-old Swiss children: accuracy and validity of reference values for body mass index from the US Centers for Disease Control and Prevention and the International Obesity Task Force. American Journal of Clinical Nutrition 2004, 79(5):838-843.

67. Frontini MG, Bao WH, Elkasabany A, Srinivasan SR, Berenson G: Comparison of weight-for-height indices as a measure of adiposity and cardiovascular risk from childhood to young adulthood: The Bogalusa heart study. Journal of Clinical Epidemiology 200I, 54(8):8I7-822.

68. Schaefer F, Georgi M, Wuhl E, Scharer K: Body mass index and percentage fat mass in healthy German schoolchildren and adolescents. International Journal of Obesity \& Related Metabolic Disorders: Journal of the International Association for the Study of Obesity 1998, 22(5):46I-469.

69. Reilly JJ, Dorosty AR, Emmett PM, team ALSPAC: Identification of the obese child: adequacy of the body mass index for clinical practice and epidemiology. International Journal of Obesity \& Related Metabolic Disorders: Journal of the International Association for the Study of Obesity 2000, 24(I2):1623-1627.

70. Mast M, Langnase K, Labitzke K, Bruse U, Preuss U, Muller MJ: Use of $B M I$ as a measure of overweight and obesity in a field study on 5-7 year old children. European Journal of Nutrition 2002, $4 I(2): 6 I-67$

7I. James PT, Leach R, Kalamara E, Shayeghi M: The worldwide obesity epidemic. Obesity Research 200I, 9 Suppl 4:228S-233S.

72. Siri WE: Body composition from fluid spaces and density: analysis of methods. In Techniques for Measuring Body Composition Edited by: Brozek J, Henschel A. Washington, DC, National Academy of Sciences / National Research Council; 1961:223-234.

73. Lohman T: Skinfolds and body density and their relation to body fatness: a review. Human Biology I98I, 53(2): 18I-225.

74. Dempster P, Aitkens S: A new air displacement method for the determination of human body composition. Medicine and Science in Sports and Exercise 1995, 27:1692-1697.

75. Francis KT: Body composition assessment using underwater weighing techniques. Physical Therapy 1990, 70(10):657-662.

76. Brodie MJ, Moscrip V, Hutcheson R: Body composition measurement: a review of hydrodensitometry, anthropometry, and impedance methods. Nutrition 1998, 14(3):296-310.

77. Fields DA, Goran MI, McCrory MA: Body-composition assessment via air-displacement plethysmography in adults and children: a review. American Journal of Clinical Nutrition 2002, 75:453-467.

78. Goran MI, Nagy TR, Treuth MS, Trowbridge C, Dezenberg C, McGloin A, Gower BA: Visceral fat in white and African American prepubertal children. American Journal of Clinical Nutrition 1997, 65(6): 1703-1708.

79. Daniels SR, Morrison JA, Sprecher DL, Khoury P, Kimball TR: Association of body fat distribution and cardiovascular risk factors in children and adolescents. Circulation 1999, 99(4):54I-545.

80. Tyrrell VJ, Richards GE, Hofman P, Gillies GF, Robinson E, Cutfield WS: Foot-to-foot bioelectrical impedance analysis: a valuable tool for the measurement of body composition in children. International Journal of Obesity 200I, 25:273-278.
81. Daniels SR, Khoury PR, Morrison JA: Utility of different measures of body fat distribution in children and adolescents. American Journal of Epidemiology 2000, I 52(12): I I79-1 I 84.

82. Slaughter MH, Lohman TG, Boileau RA, Horswill CA, Stillman RJ, Van Loan MD, Bemben DA: Skinfold equations for estimation of body fatness in children and youth. Human Biology 1988, 60(5):709-723.

83. Dezenberg CV, Nagy TR, Gower BA, Johnson R, Goran MI: Predicting body composition from anthropometry in pre-adolescent children. International Journal of Obesity 1999, 23:253-259.

84. Power C, Laker S, Cole TJ: Measurement and long-term health risks of child and adolescent fatness. International Journal of Obesity 1997, 21:507-526.

85. Wang J, Thornton JC, Bari S, Williamson B, Gallagher D, Heymsfield SB, Horlick M, Kotler D, Laferrere B, Mayer L, Pi-Sunyer FX, Pierson Jr RN: Comparisons of waist circumferences measured at 4 sites. American Journal of Clinical Nutrition 2003, 77(2):379-384.

86. McCarthy AM, Jarrett KV, Crawley HF: The development of waist circumference percentiles in British children aged 5.0-16.9y. European Journal of Clinical Nutrition 200I, 200 I:902-907.

87. Fernandez JR, Redden DT, Pietrobelli A, Allison DB: Waist circumference percentiles in nationally representative samples of African-American, European-American, and MexicanAmerican children and adolescents. Journal of Pediatrics 2004, I 45:427-430

88. Katzmarzyk P, Srinivasan S, Chen W, Malina RM, Bouchard C, Berenson G: Body Mass Index, Waist Circumference, and Clustering of Cardiovascular Disease Risk Factors in a Biracial Sample of Children and Adolescents. Pediatrics 2004, I I 4:el 198-e205.

89. Eisenmann JC: Waist circumference percentiles for 7-to I5year-old Australian children. Acta Paediatrica 2005, 94(9): I I82-II 85.

90. Ashwell M, Hsieh SD: Six reasons why the waist-to-height ratio is a rapid and effective global indicator for health risks of obesity and how its use could simplify the international public health message on obesity. International Journal of Food Sciences \& Nutrition 2005, 56(5):303-307.

91. Moreno LA, Fleta J, Mur L, Feja C, Sarria A, Bueno M: Indices of body fat distribution in Spanish children aged 4.0 to 14.9 years. Journal of Pediatric Gastroenterology \& Nutrition 1997, 25(2): $175-181$.
Publish with Biomed Central and every scientist can read your work free of charge

"BioMed Central will be the most significant development for disseminating the results of biomedical research in our lifetime. "

Sir Paul Nurse, Cancer Research UK

Your research papers will be:

- available free of charge to the entire biomedical community

- peer reviewed and published immediately upon acceptance

- cited in PubMed and archived on PubMed Central

- yours - you keep the copyright
BioMedcentral 